\title{
Study on Universities' Innovative Practice Education Approaches under Political Education Perspective
}

\author{
Junpeng Huang ${ }^{1}$ \\ ${ }^{1}$ Wuhan Textile University, Wuhan, Hubei, 430000 \\ 346591653@163.com
}

\begin{abstract}
KEYWORDS: Universities; Innovation Ideological and Political Education; Education Innovative Practice; Methods
\end{abstract}

\begin{abstract}
The mode promotion of education reform and construction has become an important direction and content of the current and future reform and development of higher education over the long term, this paper proposes the education should not only cultivates people, but also cultivates innovative practices should take talent task. Combined with actual work, this paper explores innovative practices vision of educating people in three ways under the ideological and political education of college students, namely ideological and political education and innovation practice, professional practice education and innovative practice, routine practice of combining management and innovation.
\end{abstract}

\section{Introduction}

The fundamental task of universities is to cultivate talent, quality of personnel training is the Higher Education level of most important measure. The party's 18 and the Ministry of Education, "a number of opinions on the overall improving the quality of higher education," proposed the cultivate people as the fundamental task of education; at the same time pointed out that to further promote the college educational mode reform and construction, to comprehensively strengthen and improve the quality of personnel training, cultivate students' innovative spirit and practical ability. Therefore, to promote education mode reform and construction has become an important direction and content of the current and future reform and development of higher education for a long time. Universities play in the theory of teaching the "main channel" effect at the same time, creating a second class education environment, emphasizing the practical role of education has become an important part of education reform and construction.

2010 "Long-term Education Reform and Development Plan" and in 2012 the Ministry of Education jointly issued by the ministries of the central seven "Opinions on Further Strengthening Education in higher educational work," two documents of university practice sterile practices are educating people Working to make a clear guidance and deployment. Therefore, ideological and political education not only moral education work to do, but should be tasked to develop students creative and practical ability, the service overall growth and success of students.

In the ideological and political education of college students, the function of educating people how to play the innovation practice? Author with many years of experience in education ideological and political work, he proposed the "three combinations" way. 


\section{Combination of Ideological and Political Education and Practice of Innovation}

(A) The ideal and belief education Innovation in practice

Belief is the pursuit of the highest value of life, is living in the dominant values. "CPC Central Committee and State Council on further improving and strengthening the ideological and political education," the document clearly stated: the ideal and belief education as the core depth to establish a correct outlook on life, values education is to strengthen and improve ideological and political education of college students major task one. For a long time, ideals and beliefs of education in the form of major universities are instilling education, affected its effectiveness. In the ideological and political education, should have the courage, good innovative forms of education, ideal and belief education in innovative practices, the related party line, principles, policies and socialist core values, and so contain fresh innovative practice in student activities, continued transfer positive energy to lead students to grow. The author in 2014 organized to lead students to go to Yichang to carry out "practice the socialist core values, to pursue a dream of farmers get rich" social practice, and actively guide students around the "socialist core values" social hot spots, to carry out the actual research; after the end of practice, organized students to "the theory of Sharon" in the form of social practice to sort out, discuss and summarize, through practice so that students deeply felt: "Socialist core values not far from us, with their expertise to serve the grassroots people themselves In practice the socialist core values. " Through practice, not only the college students to cultivate and practice the socialist core values, ideals and beliefs education will be better integrated into the practice; at the same time, not afraid of hardship hone student spirit, so they will be more firm, to enhance the students' identity of national policies and the party's theoretical knowledge. .

(B) The students sense of social responsibility Innovation in practice

Current social responsibility consciousness of college students is relatively weak, as a special group of high intellectual and cultural level, the strength of the relationship between social responsibility to the rise of the country's future and destiny of the Chinese nation. Central on the 16th document "to further strengthen and improve ideological and political education opinion" clearly states that, to make "Students know the destiny of the country, aware of their social responsibility, enhance social responsibility"; the party's 18 report also proposed a "culture of social responsibility," the educational mission. Universities can actively organize students to participate in volunteer activities such as innovative practice and public service activities, improve students' awareness of social responsibility; at the same time, we should actively build innovative practice platform for the students. I students in the nursing home long-term volunteer service, Zhang students noticed a phenomenon: an old man backs suddenly itch to scratch the itch but difficult position. This idea has been supported by the author. Through the efforts of automatic scratching back massager was born, and successfully applied for patent. Zhang students feeling that, in the process of the invention, not only to exercise the ability to innovate, more important is to solve a problem of the elderly, compared to the patented invention, capable of a dedicated force for the elderly and community feel more happy. Exploratory practice of educating people to bring unexpected harvest, to help students take the initiative to integrate themselves into the process of development of the whole society, to think and practice, burst out of social concern and social responsibility as a youth.

\section{The Combination of Routine Practice of Management and Innovation}

(A) The management of daily affairs to explore the potential of students' innovative practice 
In the daily management of the affairs, the students are thinking but also student work must be of concern, on the one hand, can improve the effectiveness of ideological and political education; on the other hand, helps students to play in the work of student creativity, culture Students' Innovative Practice initiative. The author in August 2013, when the online New Year, Liu students presented before enrollment for the school to do whatever contribution, as a memorial next four years of college. After seeing the proposal, I think it should be supported, finalized to bring home a piece of cobblestone report when each student enrolled, the school, the paved a "road students." The "Golden Ideas" at New Year, but also by more than 10 news media attention. After school, I arranged the students as a squad leader Liu, Liu guide students to participate in the innovation practice, and received a series of awards, published in the journal 4; Liu students under the guidance of four one-time pass rate where the classes up to 100\%. In July 2015 he organized his classmates to carry out social practice, won the provincial excellent team. By "to point", greatly improved the students' enthusiasm for innovative practice.

(B) Class group construction of students' innovative practice platform

In the daily class construction and management, to take advantage of good second, third class, the class as a unit established innovation practice groups, organizations such as "I and the flag together a shadow", "I love to remember the word" and other colorful innovative activity, innovative efforts to mobilize the enthusiasm of the students; at the same time, continue to strengthen the system construction, the establishment of a school, college, class three innovative incentives and evaluation system, stimulate the enthusiasm of students' innovative practice, improve class group cohesion. In the class group construction, but also good means of "external forces" and invited experienced, good guide innovative internal and external experts to guide students to carry out innovative practices, innovative practice activities for students to build a platform to guide

\section{The Combination of Professional Practice Education and Innovation Practice}

(A) Professional practice to guide students to enhance their professional skills

"The Ministry of Education and other departments Several Opinions on Further Strengthening Education in higher educational work," pointed out, practice teaching is an important part of the school teaching, students acquire, acquire knowledge of important ways. Innovation practice, especially the practice of professional practice is an important way of educating people. Practice base is to carry out the important work of educating people carrier practice, universities should actively explore the campus practice base for student education and training base, through colleges, enterprises, schools and the introduction of other ways, and actively recommend students to participate in extracurricular professional practice exchange activities to enhance students' professional practice skill. Professional practice can not only open up their horizons, to enhance students 'professional skills, but also help clarify students' future career directions.

(B) To enhance students' professional competition in professional self-confidence

Professional competition is based on the close integration of classroom teaching, to contest the method to stimulate students to integrate theory with practice and the ability to work independently, to enhance students' confidence in learning and work activities. Professional competition is a useful education, teaching behavior, not with conventional teaching and innovative educational function, not only can help students develop a keen interest in science, while helping to make knowledge structure with the development of pioneering learning methods of inquiry, the pursuit of psychological quality of truth. Therefore, colleges and universities should actively organize students to participate in various professional disciplines competitions at all levels, to enable students to enhance their professional confidence and professional skills in the contest. 
(C) To help improve students' innovative research practice application ability

Introduced into the science undergraduate student education, especially the education process, help the students to carry out research activities, not only can develop students' practical ability and creative spirit, and "application" and "innovative" double standard personnel training, and can promote students In research practice activities to help improve the professional knowledge and scientific research ability, cultivate student interest in science and innovation, stimulate the courage to explore, develop, explore and create potential.

Innovative Practice Education in Colleges depth implementation of quality education, vigorously improve the quality of higher education an inevitable requirement, is the only way for College Students' Growth Overall, university education work practice innovation university personnel training is still the weak link, the need Universities vigorously innovation and reform in their work.

\section{REFERENCES}

[1] Chen Changxing. Ideological Education and Innovative Talents. [J]. Road to Success, 2015, (01)

[2] Xu Mei. Explore the Ideological and Political Education Based on The Theory of Social Practice [J]. China Electric Power Education, 2014, (05).

[3] Yin Lulu. Research on Ideological and Political Education of College Students' Creative Ability [J]. China Electric Power Education, 2013, (06).

[4] Ma Fei. Political Education Creative Talents People under Horizon College Ideological [J]. Hengshui University, 2013 (05).

[5] Miao Xuelian, Wang Xianjun. Explore Life on the Ideological and Political Education Practice [J]. Socialism Institute, 2013, (01).

[6] Tao Yongcheng. Innovative Research based on Ability to Enhance the Professional Practice of Educational Practice Mode [J]. Chinese Vocational and Technical Education, 2012, (12).

[7] Xie Qimei. Enhanced Awareness and Optimizing the Practice of Ideological and Political Education [J]. Moral and Construction, 2007 (12).

[8] Chenshu Wen. Ideological and Political Education and Innovation Ability of College Students [J]. Theoretical Survey, 2009, (05). 